http://ejournal.upi.edu/index.php/jaz - e-mail: jurnal_zonasi@upi.edu

doi.org/10.17509/jaz.v4i2.31786

\title{
KARAKTERISTIK TERMAL RUMAH BATU EKSPOS DI TROPIS PEGUNUNGAN (Studi Kasus di Desa Kwadungan, Wonosobo)
}

$$
\begin{aligned}
& \text { Article History: } \\
& \text { First draft received: } \\
& 1 \text { Maret } 2021 \\
& \text { Revised: } \\
& 10 \text { April } 2021 \\
& \text { Accepted: } \\
& 11 \text { April } 2021 \\
& \text { Final proof received: } \\
& \text { Print: } \\
& \text { 15 Juni } 2021 \\
& \text { Online } \\
& \text { 15 Juni } 2020
\end{aligned}
$$

Jurnal Arsitektur ZONASI is indexed and listed in several databases:

\section{SINTA 4 (Arjuna)}

GARUDA (Garda Rujukan Digital) Google Scholar

Dimensions

oneSearch

BASE

\section{Member: \\ Crossref \\ RJI}

APTARI

FJA (Forum Jurna Arsitektur) IAI

AJPKM

\author{
Hermawan ${ }^{1}$ \\ Agus Hindaryanto ${ }^{2}$ \\ Atat Taoda ${ }^{3}$ \\ 1,2,3 Universitas Sains Al-Qur'an, Wonosobo, Indonesia \\ Jl. Hasyim Asy’ari Km.03 Wonosobo \\ Email: ${ }^{1}$ hermawanarsit@gmail.com \\ 2 agoeshindaryanto@gmail.com \\ 3atataoda2@gmail.com
}

Abstract: Waste of Energy is an interesting issue to discuss. One of the energy wastes occurs in buildings in maintaining thermal comfort for occupants. Energy waste in buildings is caused by cooling equipment that uses large amounts of energy due to the hot climate outside the building. The use of equipment to create thermal comfort for residents also occurs in cold regions. However, the heating equipment (fireplace) used uses wood fuel that is obtained from nature. The use of a fireplace affects the thermal characteristics of the building. Besides the fireplace, the physical condition of the building also affects the thermal comfort of the occupants. One of the buildings that are considered capable of creating thermal comfort is a vernacular building. In the highlands there are vernacular buildings with exposed stone walls. This research will reveal the thermal characteristics of stone houses exposed in mountainous areas. This research uses quantitative methods with a strategy of measuring thermal variables using a thermal measuring device. The variables measured include air temperature, air humidity, wind speed, and average solar radiation temperature. There are 5 buildings studied. Analysis using descriptive which explains the graph of the results of the data recap. The analysis is related to the physical condition of the building. The results showed that the thermal characteristics of exposed stone houses were able to make climate variables acceptable to residents. Fireplaces are a local element that is often lit to add to the thermal comfort of the residents. The use of fireplaces with wood fuel does not create a waste of fossil energy that is too high.

\section{Keywords: Thermal; stone house; mountainous}

Abstrak: Pemborosan Energi menjadi isu yang menarik untuk dibahas. Salah satu pemborosan energi terjadi pada bangunan dalam mempertahankan kenyamanan termal penghuni. Pemborosan energi pada bangunan diakibatkan adanya peralatan pendinginan yang menggunakan energi besar akibat iklim panas di luar bangunan. Penggunakan peralatan untuk menciptakan kenyamanan termal penghuni juga terjadi pada wilayah dingin. Namun, peralatan penghangatan (perapian) yang digunakan menggunakan bahan bakar kayu yang didapat dari alam. Penggunaan perapian mempengaruhi karakteristik termal bangunan. Selain perapian, kondisi fisik bangunan juga mempengaruhi kenyamanan termal penghuni. Salah satu bangunan yang dianggap mampu menciptakan kenyamanan termal adalah bangunan vernakular. Pada wilayah dataran tinggi terdapat bangunan vernakular berdinding batu ekspos. Penelitian ini akan mengungkap karakteristik termal rumah batu ekspos di wilayah pegunungan. Penelitian menggunakan metode kuantitatif dengan strategi pengukuran variabel termal dengan menggunakan alat pengukur termal. Variabel yang diukur diantaranya adalah suhu udara, kelembaban udara, kecepatan angin, suhu radiasi matahari rata-rata. Bangunan yang diteliti berjumlah 5 buah. Analisis menggunakan deskriptif yang menjelaskan grafik hasil rekap data. Analisis dikaitkan dengan kondisi fisik bangunan. Hasil penelitian menunjukkan bahwa karakteristik termal rumah batu ekspos mampu membuat variabel iklim diterima oleh penghuni. Perapian menjadi unsur lokal yang sering dinyalakan untuk menambah kenyamanan termal penghuni. Penggunaan perapian dengan bahan bakar kayu tidak menciptakan pemborosan energi fosil yang terlalu tinggi.

Kata Kunci: termal; rumah batu; pegunungan 


\section{Pendahuluan}

Ketidaknyamanan termal pada bangunan selalu berimbas pada pemborosan energi. Pada daerah dengan suhu udara yang panas akan membuat penghuni menggunakan peralatan pendinginan seperti Air Conditioning (AC). Penggunaan peralatan tersebut membuat penggunaan energi menjadi meningkat sehingga menyebabkan pemborosan energi. Kenyamanan termal menjadi salah satu aspek yang digunakan untuk memprediksi penciptaan kenyamanan termal bagi penghuni bangunan (Hermawan, 2014). Rumah vernakular banyak diyakini mampu menciptakan kenyamanan termal tanpa adanya tambahan peralatan pendinginan. Rumah dengan material kayu menjadi ciri khas rumah material di daerah tropis panas (Hermawan \& Fikri, 2020). Penciptaan kenyamanan termal penghuni yang dilakukan dengan pengolahan aspek bangunan dikenal dengan pendinginan pasif. Desain arsitektur akan tercipta dengan baik dalam mencapai kenyamanan termal dengan adanya strategi pendinginan pasif. Penggunaan elemen bangunan bisa digunakan untuk melakukan pendinginan maupun penghangatan di dalam ruang (Hakiki et al., 2020).

Daerah tropis tidak hanya mempunyai satu karektiristik iklim saja. Pada wilayah tropis pegunungan mempunyai karakteristik iklim yang berbeda dengan dataran rendah. Kondisi iklim yang dingin membuat penghuni bangunan menyesuaikan diri dengan iklim yang ada. Penyesuaian diri tersebut terkait dengan aspek personal dan aspek fisik bangunan. Penyesuaian diri penghuni untuk menciptakan kenyamanan termal dikenal dengan kenyamanan termal adaptif (Hermawan, 2018). Penyesuaian diri penghuni juga dilakukan dengan menjadikan peralatan untuk menciptakan kenyamanan termal. Penghuni di daerah pegunungan sering menyalakan perapian untuk membuat penghangatan ruang. Perapian yang digunakan menggunakan bahan bakar kayu yang didapat dari lingkungan sekitar. Pencarian kayu untuk bahan bakar perapian dikenal dengan nama repek yang didapat tanpa menebang pohon. Repek dilakukan dengan mencari ranting-ranting yang jatuh dari pohon sehingga tidak membuat kerusakan alam akibat penebangan pohon. Penggunaan perapian yang mengambil bahan bakar kayu dengan cara repek akan menciptakan keberlanjutan (Hermawan \& Prianto, 2018).

Daerah tropis pegunungan mempunyai rumah tinggal lokal yang memanfaatkan material setempat sebagai bahan bangunan pembentuk dinding. Material menjadi penting dalam menciptakan kenyamanan termal penghuni. Penggunaan material untuk selubung bangunan di dataran tinggi membuat perbedaan hasil variabel iklim dalam suatu bangunan (Hermawan et al., 2019). Selain material, ventilasi menjadi faktor penting pembentuk kenyamanan termal bagi penghuni bangunan. Aspek kenyamanan termal membuat aktivitas di dalam bangunan menjadi berhasil dilakukan dengan baik. Ventilasi tidak hanya terkait dengan besaran ukuran saja namun juga terkait dengan peletakan, orientasi dan jenis ventilasinya (Vidiyanti et al., 2020). Selain itu, iklim tropis sangat mempengaruhi tata ruang dan tata letak bangunan dalam sebuah permukiman. Beberapa hasil penelitian memperlihatkan bahwa permukiman tradisional sangat memperhatikan aliran angin pada suatu wilayah. Orientasi rumah tinggal dikaitkan dengan peletakan gunung yang terkait dengan aliran angin gunung maupun angin lembah. Penerapan arsitektur tropis menjadi terlihat pada permukiman tradisional (Aprita \& Anisa, 2020). Pentingnya elemen bangunan dalam penciptaan kenyamanan termal khususnya di daerah tropis pegunungan menjadi dasar dari penelitian ini. Tujuan penelitian adalah mengungkap karakteristik termal dari rumah tinggal batu ekspos di daerah pegunungan.

\section{Metode Penelitian}

Penelitian dilakukan dengan melakukan pengukuran variabel termal yang dianalisis secara deskriptif. Variabel termal yang diukur meliputi suhu udara, suhu radiasi matahari, kelembaban udara, kecepatan angin. Penelitian dilaksanakan di Dusun Klowoh Desa Kwadungan Kecamatan Kalikajar Kabupaten Wonosobo. Desa tersebut terletak di kaki gunung sumbing. Penelitian menggunakan 5 buah rumah sebagai obyek penelitian. Rumah yang diambil mempunyai dinding yang terbuat dari batu ekspos. Pengukuran variabel termal dilakukan setiap setengah jam sekali. Peletakan alat ukur diletakkan di tengah ruangan dengan menggunakan penyangga alat (tripod). Selain pengukuran variabel termal dengan menggunakan alat, dilakukan observasi tentang kondisi fisik bangunan. Penggambaran dilakukan untuk memperoleh tampilan bangunan. Selain penggambaran 2D juga dilakukan dokumentasi dengan kamera pada setiap ruang yang ada. Analisis deskriptif digunakan untuk mengungkap karakteristik termal yang dikaitkan dengan kondisi fisik bangunan. 


\section{Hasil dan Pembahasan}

Pembahasan dilakukan dengan menguraikan kondisi fisik masing-masing rumah tinggal yang dijadikan obyek penelitian. Jenis ruang yang ada pada obyek penelitian meliputi ruang tamu, kamar tidur, tritisan, pawon, kamar mandi. Pengukuran tidak dilakukan pada kamar mandi. Pengukuran dilakukan juga pada ruang luar agar didapat iklim mikro pada masing-masing lingkungan rumah tinggal.

\subsection{Kondisi Fisik Rumah Bapak Supoko}

Pondasi yang digunakan adalah pondasi batu kali namun untuk lantai rumah ini masih berlantai tanah belum menggunakan semen/peluran. Dinding menggunakan pasangan batu kali tanpa plaster. Jendela terbuat dari kayu dan kaca sebagai pengisinya. Atap menggunakan atap seng gelombang dan semua dari ruangan belum diberi plafon. Dapur (pawon) mempunyai rak yang dikenal dengan nama poro/pyan yang difungsikan untuk menyimpan barang atau kayu persedian sehari hari sebagai bahan bakar. Penghuni masih mengutamakan pawon sebagai alat pengganti kompor minyak dibandingkan dengan kompor gas. Penggunaan perapian menjadi dominan pada rumah tinggal Bapak Supoko.
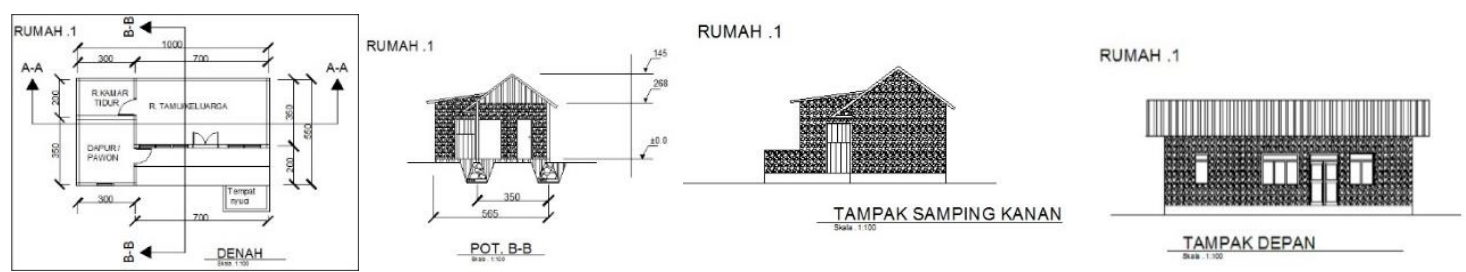

Gambar 1. Denah, Tampak dan Potongan Rumah Pertama (Sumber: analisis, 2021)

Pintu yang berhubungan dengan ruang luar terdapat celah yang ada celahnya berukuran sekitar $2 \mathrm{~cm}$ dan berwana natural. Tidak ada plafon yang terpasang di rumah tersebut karena langsung dipasangkan atap seng bjls bergelombang. Bentuk atap berbentuk atap pelana dan ada celah atau bukaan sehingga angin bisa masuk. Terdapat 1 ruang keluarga, 1 ruang kamar, 1 ruang tamu dan 1 ruang dapur, warna dominasi perabot masih berwarna mentah/natural kayu. pada ruang tamu terpasang 4 jendela kaca yang bisa dibuka namun tidak pernah dibuka, pada ruang kamar terpasang 1 jendela per ruang nya dan jendela tidak bisa dibuka, pada ruang keluarga terpasang 2 jendela dan tidak bisa dibuka/mati. Arah hadap menghadap ke Selatan. Ruang tamu terletak di depan dan menyatu dengan ruang keluarga dan bertemu muka dengan ruang luar dan pada sebelah ruang kamar, dan pada ruang tersebut tidak terkena sinar matahari pagi, dan yang terkena sinar matahari pagi adalah ruang tamu pada sore hari. Tidak terdapat satupun tanaman yang ditanam yang bisa mempengaruhi termal. Jarak dari rumah tersebut ke rumah yang lainnya sekitar 1.5 meter. kebiasaan yang dilakukan adalah dengan duduk lesehan dan duduk di kursi kayu, pada jam 6 pagi tidak membuka jendela hanya dibuka kain kordennya saja dan menutupnya dengan kain korden pada jam 5 sore. Pakaian yang dipakai biasanya ganti dua kali pada pagi hari dan sore hari, dan berbahan katun. Untuk menghangatkan tubuh menggunakan pawon (tungku masak yang dihadapkan ke badan agar terasa hangat.

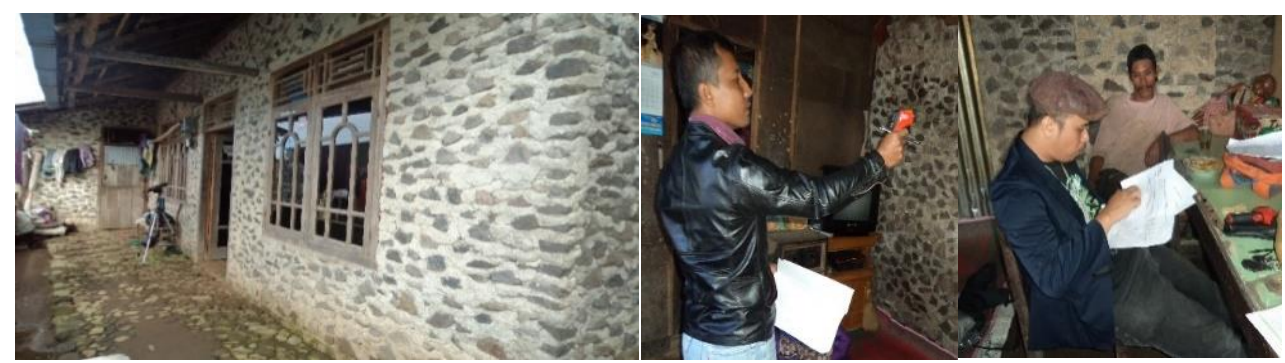

Gambar 2. Tampilan Rumah Pertama (Sumber: analisis, 2021)

Dari hasil penelitian yang dimulai pagi hari pukul 07.00 WIB hingga petang pukul 18.00 WIB didapat hasil terendah atau minimum dari suhu ruang dapur yaitu $22.1^{\circ} \mathrm{C}$ pada pukul $07.00 \mathrm{WIB}$ dan pukul 17.00. Kelembaban terendah atau minimumnya pada dapur adalah $75 \%$ yaitu pukul 12.00 WIB. Hasil maksimum atau suhu tertinggi di ruang ini adalah $26.9^{\circ} \mathrm{C}$ pada pukul 14.00 WIB dan kelembaban maksimumnya adalah $81 \%$ pada pukul 07.30 WIB, 08.00 WIB dan 14.30 WIB. Suhu rata-rata di dapur tersebut yaitu $24.1^{\circ} \mathrm{C}$ dan kelembaban rata-ratanya adalah $79 \%$. Pada ruang tamu didapat suhu minimum atau suhu terendah pada ruang tamu tersebut yaitu $20.0^{\circ} \mathrm{C}$ dan hasil minimum atau kelembaban terendahnya diruang tamu ini adalah $70 \%$. 
Untuk suhu tertinggi atau suhu maksimum yang muncul pada ruang tamu ini adalah $24.7^{\circ} \mathrm{C}$ dan kelembaban maksimumnya adalah $85 \%$. Rata-rata pada ruang tamu adalah $22.5^{\circ} \mathrm{C}$ dan rata-rata kelembabannya adalah 75 $\%$. Tritisan pada rumah ini mempunyai suhu terendah atau suhu minimumnya sebesar $20.0{ }^{\circ} \mathrm{C}$. Kelembaban pada tritisan rumah ini adalah $67 \%$. Suhu tertinggi pada tritisan adalah $23.8^{\circ} \mathrm{C}$. Kelembaban maksimumnya adalah $91 \%$. Rata-rata suhu yang didapat adalah $22.3{ }^{\circ} \mathrm{C}$. Rata-rata kelembabanya adalah $76 \%$. Pada ruang tidur didapat suhu terendah atau suhu minimum sebesar $20.00{ }^{\circ} \mathrm{C}$ yang terjadi pada pukul 11.30 WIB. Kelembaban minimumnya adalah $67.40 \%$ pada pukul $16.00 \mathrm{WIB}$, sedangkan suhu tertinggi yang didapat pada ruang ini adalah $24.70^{\circ} \mathrm{C}$. Suhu tersebut terjadi pada pukul 13.30 WIB. Kelembaban tertinggi adalah 78.10 $\%$. Rata-rata suhu di ruang ini adalah $22.40{ }^{\circ} \mathrm{C}$. Rata-rata kelembaban pada ruang ini adalah $72.99 \%$.

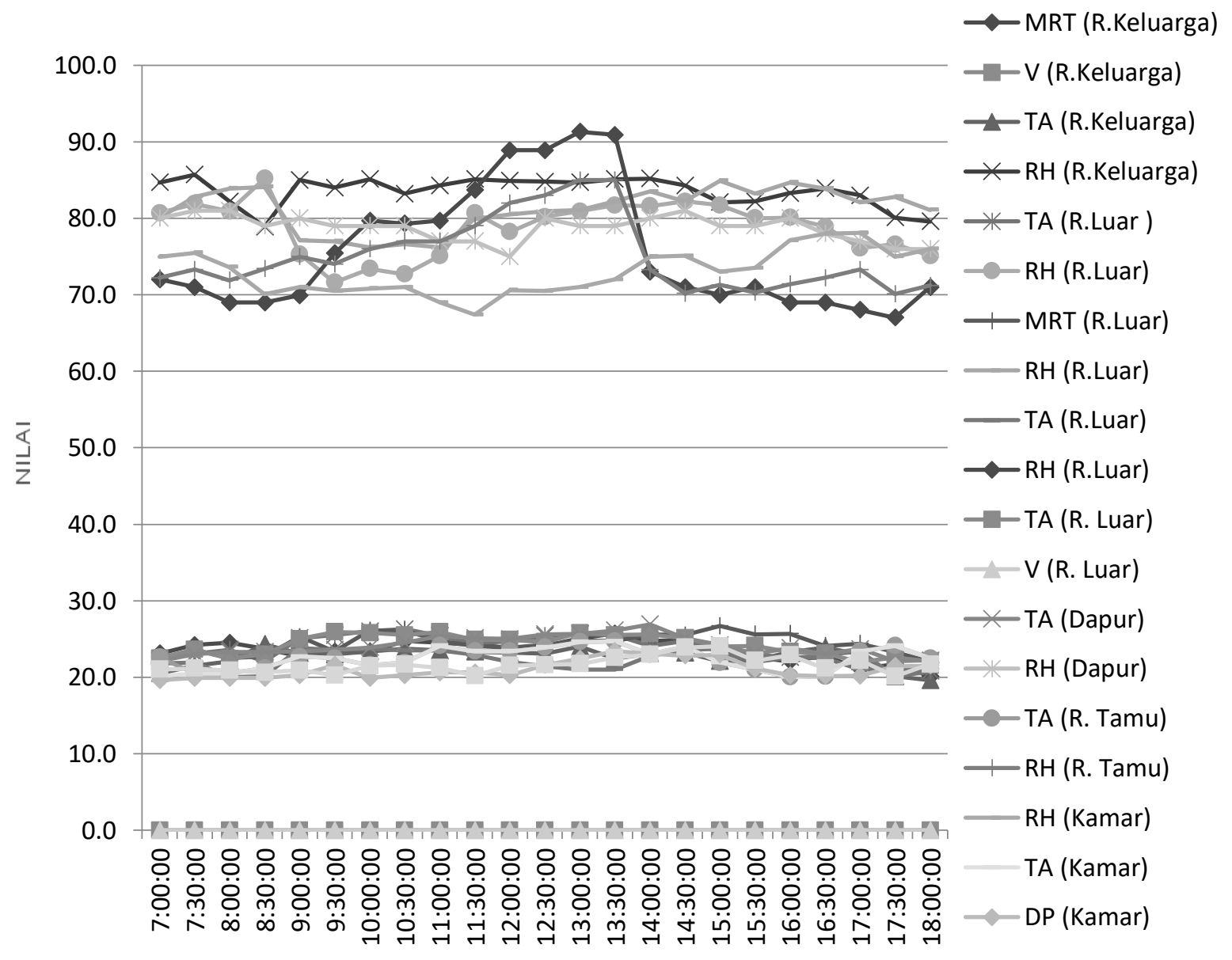

Gambar 3. Grafik Variabel Termal Rumah Pertama (Sumber: analisis, 2021)

Suhu tertinggi terjadi pada kamar tidur yaitu mencapai $24.7{ }^{\circ} \mathrm{C}$ dengan kelembaban $78.10 \%$. Suhu terendah terjadi di tritisan rumah dan kamar tidur yaitu $20.0^{\circ} \mathrm{C}$ dengan kelembaban $67.40 \%$ dan $67 \%$. Kecepatan angin tidak begitu terlihat karena sebagian besar kecepatan angin memperlihatkan nilai yang kecil. Kecepatan angin mulai dari $0-0.1 \mathrm{~m} / \mathrm{s}$. Suhu radiasi matahari rata-rata tidak jauh berbeda dengan suhu udara sehingga pembahasan ditekankan pada suhu udara dan kelembaban udara.

\subsection{Kondisi Fisik Rumah Ibu Tuanto}

Kondisi rumah ibu Tuanto dengan pondasi batu kali sebagai pondasi rumahnya, lantai tanah serta dinding menggunakan kayu mahoni dan suren, belum diplafon. Sebelah timur dan utara merupakan rumah tetangga yang berjarak sekitar 1,5 m sehingga bukaan yang ada pada rumah ini terkesan kurang leluasa mendapatkan cahaya matahari dan udara. Cahaya matahari tidak bisa dirasakan oleh penghuni rumah hingga menjelang siang hari. Rumah kurang mendapatkan pencahayaan dan penghawaan yang baik pada pagi hari karena rumah tertutup bangunan lain. 

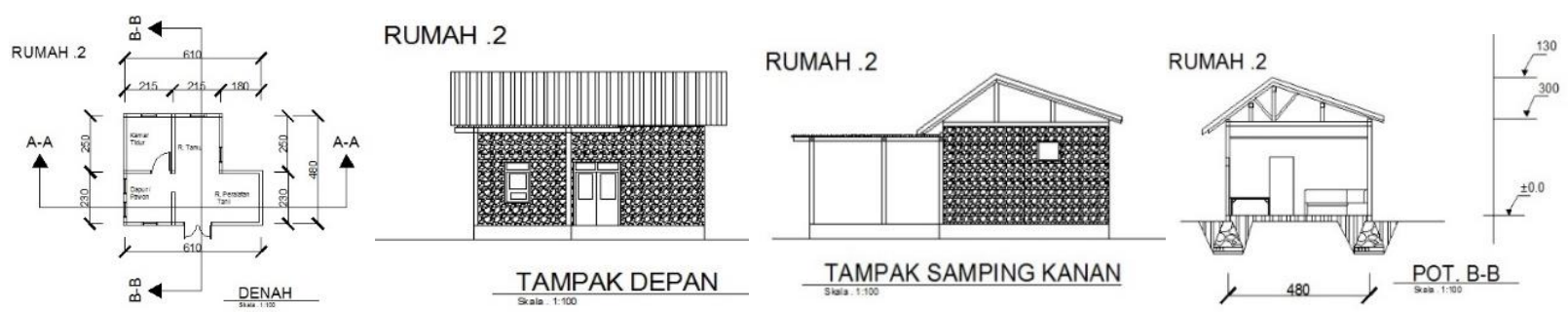

Gambar 4. Denah, Tampak dan Potongan Rumah Kedua (Sumber: analisis, 2021)

Rumah tinggal tidak mempunyai plafon. Bentuk atap berbentuk atap pelana dan mempunyai celah atau bukaan di bawah atap sehingga angin bisa masuk ke dalam bangunan. Rumah tinggal terdiri dari 1 ruang tamu, 1 ruang keluarga 1 ruang kamar dan 1 ruang dapur. Rumah tinggal mempunyai 2 daun jendela pada ruang tamu, 1 jendela pada setiap kamar. Jenis jendela di ruang tamu merupakan jendela mati dan tidak bisa dibuka untuk mendapatkan penghawaan. Jendela difungsikan untuk pencahayaan. Jendela kamar tidur biasa dibuka pada pukul 08.00 dan ditutup kembali pada pukul 16.00 WIB. Arah hadap rumah tinggal menghadap ke Barat. Letak ruang tamu di sebelah timur, ruang keluarga dan ruang dapur di sebelah utara, kamar tidur di sebelah timur bersebelahan dengan ruang tamu. Ruang yang mendapat sinar matahari pada pagi hari adalah ruang tamu. Rumah tinggal tidak mempunyai tanaman di sekitar rumah. Jarak rumah dengan rumah sebelah sekitar 1 meter. Kebiasaan duduk penghuni memakai dingklik/jengkok dan kursi. Pakaian yang dipakai biasanya ganti dua kali pada pagi hari dan sore hari, dan berbahan katun. Untuk menghangatkan tubuh menggunakan paw on (tungku) yang dihadapkan ke badan agar terasa hangat.

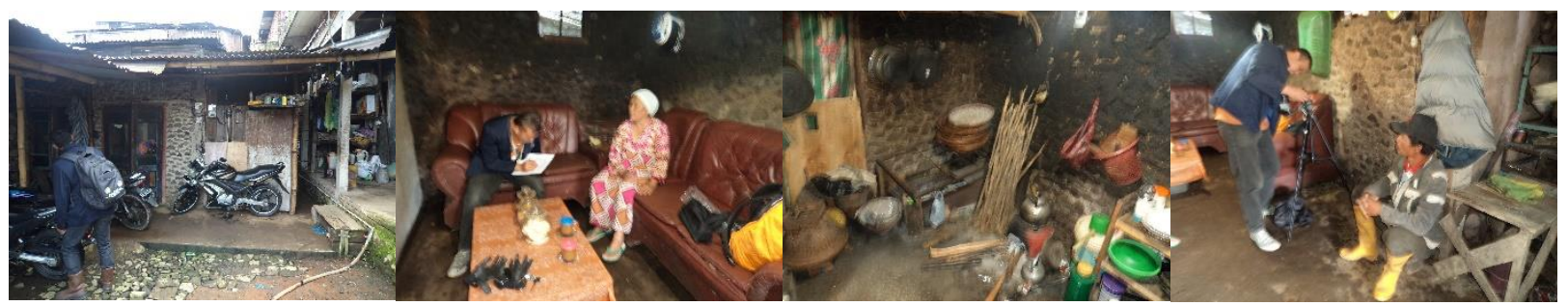

Gambar 5. Tampilan Rumah Tinggal Kedua (Sumber: analisis, 2021)

Dapur (pawon) mempunyai suhu minimum sebesar $20.1^{\circ} \mathrm{C}$ pada pukul 17.30 WIB. Kelembaban terendah atau minimum pada ruangan dapur adalah $73 \%$ yang terjadi pada pukul $09.00 \mathrm{WIB}$. Suhu tertinggi adalah $23.7^{\circ} \mathrm{C}$ dan kelembaban tertinggi adalah $85 \%$ yang terjadi pada pukul 15.00 WIB. Suhu udara rata-rata di dapur yaitu $22.3^{\circ} \mathrm{C}$. Kelembaban rata-ratanya adalah $80 \%$. Suhu minimum atau suhu terendah pada ruang tamu yaitu $20.8{ }^{\circ} \mathrm{C}$ yang terjadi pada pukul $17.30 \mathrm{WIB}$. Kelembaban terendahnya adalah $72 \%$ terjadi pada pukul 07.00 WIB. Suhu udara tertinggi adalah $23.9^{\circ} \mathrm{C}$ terjadi pada pukul 08.00 WIB. Kelembaban maksimumnya adalah $86 \%$ terjadi pada pukul 14.30 dan 15.00 WIB. Rata-rata suhu udara pada ruang tamu tersebut adalah $22.7^{\circ} \mathrm{C}$. Rata-rata kelembaban ruang tamu adalah $80 \%$. Tritisan mempunyai suhu terendah sebesar $20.1{ }^{\circ} \mathrm{C}$. Kelembaban terendah adalah $70 \%$. Suhu udara tertinggi adalah $23.6{ }^{\circ} \mathrm{C}$. Kelembaban maksimumnya adalah $85 \%$. Rata-rata suhu udara adalah $22.1^{\circ} \mathrm{C}$. Rata-rata kelembabannya adalah $78 \%$. Suhu minimum ruang tidur adalah $21.01^{\circ} \mathrm{C}$. Kelembaban minimumnya sebesar $82.18 \%$. Suhu udara tertinggi sebesar $23.35^{\circ} \mathrm{C}$. Kelembaban maksimumnya adalah $90.50 \%$. Rata-ratan suhu udara adalah $22.24^{\circ} \mathrm{C}$. Rata-rata kelembabannya sebesar $86.21 \%$. 


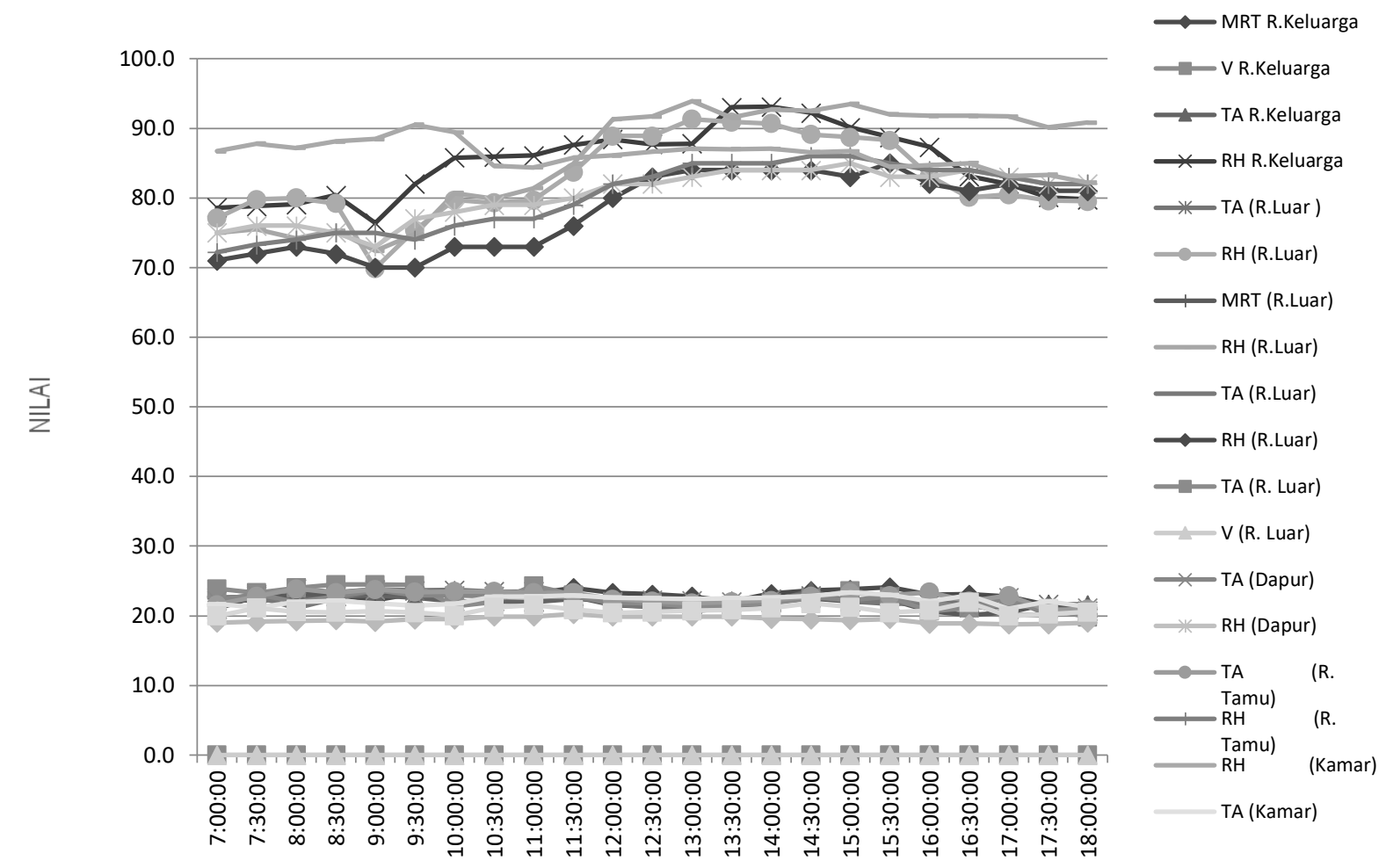

Gambar 6. Grafik Variabel Termal Rumah Kedua (Sumber: analisis, 2021)

Suhu tertinggi pada rumah ini berada terjadi di dapur karena aktifitas yang ada cenderung aktif. Dapur lebih sering dijaadikan kegiatan utama keluarga bila sedang di rumah. Aktivitas yang dilakukan berkumpul dan makan bersama keluarga. Selain itu, tetangga sebelah ikut serta dalam kegiatan berkumpul. Penggunaan perapian di dapur menjadi lebih aktif. Ruang tamu cenderung lebih dingin akibat tidak begitu berfungsinya ruang tamu untuk aktivitas. Ruang tamu hanya digunakan untuk menerima tamu dari jauh. Pada saat ada tetangga yang akan bertamu kecenderungan diterima di dapur sambil menghangatkan badan. Penghuni jarang menerima tamu dari jauh sehingga aktivitas pada ruang tamu kurang.

\subsection{Kondisi Fisik Rumah Bapak Harmanto}

Rumah tinggal menggunakan pondasi batu kali, lantai plasteran dan dinding bermaterial batu. Jendela depan menggunakan kaca. Atap menggunakan material seng dan sebagian langit-langit sudah menggunakan plafon dari tripleks. Letak rumah menghadap selatan yang berbatasan langsung dengan tembok penahan tanah setinggi 2.5 meter. Sebelah timur berbatasan dengan rumah tetangga, sebelah utara terlihat ada tebing. Sinar matahari mampu masuk ke dalam rumah dengan baik akibat batas dengan rumah tetangga tidak terlalu dekat.
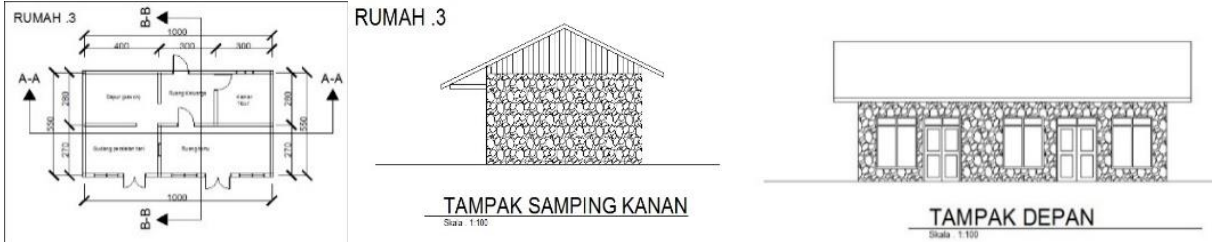

RUMAH

Gambar 7. Denah, Tampak dan Potongan Rumah Ketiga (Sumber: analisis, 2021)

Rumah tinggal sebagian sudah berplafon, namun sebagian belum ada plafon. Bentuk atap berbentuk atap pelana dan ada banyak celah atau bukaan sehingga angin mudah masuk. Rumah Tinggal mempunyai 1 ruang tamu, 1 kamar tidur, 1 ruang dapur. Pada ruang tamu terpasang 4 daun jendela yang terpisah dengan pintu. Setiap kamar mempunyai 1 jendela. Dapur mempunyai 2 bouven. Arah hadap rumah menghadap ke Utara. Ruang yang intensitasnya lebih tinggi mendapatkan sinar matahari adalah ruang dapur dan ruang tamu. Tidak terdapat sedikitpun tanaman sebagai vegetasi rumah tersebut. Jarak antara satu rumah dengan yang lainnya adalah 2 meter pada samping rumah, dan pada depan 3 meter berhadapan dengan tembok penahan tanah jalan 
di atasnya setinggi 1,5m. Karpet dan dampar/dingklik/jengkok digunakan pada ruang keluarga. Kursi kayu digunakan di ruang tamu. Jendela pada ruang tamu tidak bisa dibuka karena menggunakan jendela mati. Jendela pada kamar dan dapur biasa dibuka pada pukul 7 dan ditutup kembali pada pukul 4 sore. Seperti halnya penghuni rumah lainnya, pakaian yang dipakai biasanya ganti dua kali pada pagi hari dan sore hari, dan berbahan katun. Penghangatan tubuh juga menggunakan perapian seperti halnya rumah lainya.

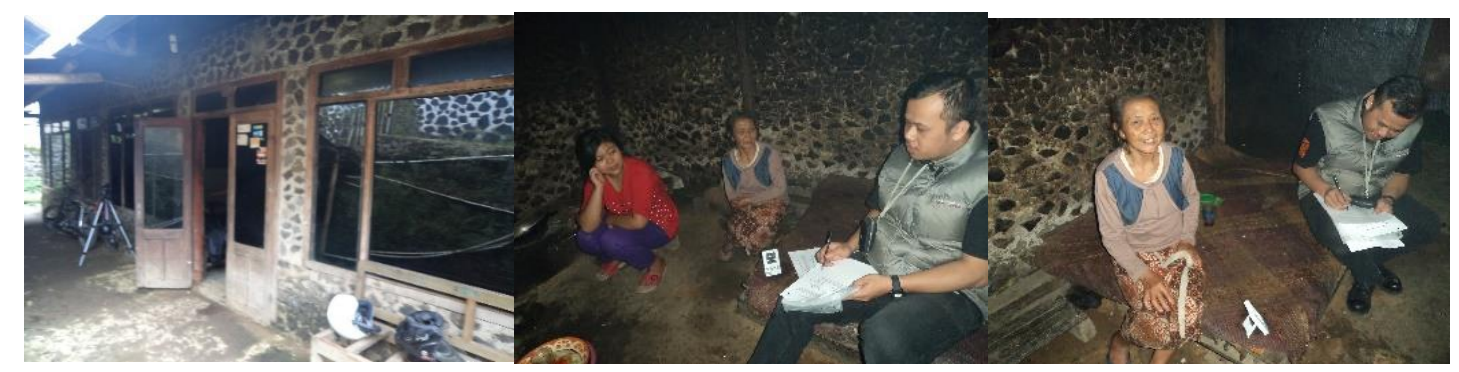

Gambar 8. Tampilan Rumah Tinggal Ketiga (Sumber: analisis, 2021)

Ruang dapur (pawon) mempunyai suhu minimum sebesar $22.1^{\circ} \mathrm{C}$ yang terjadi pada pukul 07.00 dan 17.30 WIB. Kelembaban minimal sebesar $75 \%$ yang terjadi pada pukul 12.00 WIB. Suhu tertinggi terjadi pada pukul 14.00 WIB sebesar $26,9^{\circ} \mathrm{C}$. Kelembaban sebesar $81 \%$ terjadi pada pukul 14.30 WIB. Rata-rata suhu udara pada pukul 07.00 WIB hingga pukul 18.00 WIB sebesar $24.1^{\circ} \mathrm{C}$ dan kelembaban rata-ratanya sebesar $79 \%$. Suhu minimum ruang tamu yaitu $20.0^{\circ} \mathrm{C}$. Kelembaban minimumnya adalah $70 \%$. Suhu tertinggi sebesar $24.7^{\circ} \mathrm{C}$ dan kelembaban maksimumnya adalah $85 \%$. Suhu udara rata-rata yang terjadi yaitu sebesar $22.5^{\circ} \mathrm{C}$ dan kelembaban rata-ratanya adalah $75 \%$. Suhu terendah pada tritisan yaitu $20.0{ }^{\circ} \mathrm{C}$, dan kelembaban minimalnya adalah $67 \%$. Suhu tertinggi sebesar $23.8^{\circ} \mathrm{C}$ dan kelembaban maksimumnya adalah $91 \%$. Suhu udara rata-rata adalah $22.3{ }^{\circ} \mathrm{C}$ dan kelembaban rata-ratnya adalah $76 \%$. Suhu terendah atau minimum di kamar tidur yaitu $20.0{ }^{\circ} \mathrm{C}$ yang terjadi pada pukul 16.00 WIB. Kelembaban minimunya adalah $67.4 \%$. Suhu maksimum sebesar $23.1^{\circ} \mathrm{C}$ dan kelembaban maksimumnya adalah $78.1 \%$, Suhu rata rata di kamar tidur yaitu $22.4^{\circ} \mathrm{C}$ dan rata-rata kelembabannya adalah $73.0 \%$.

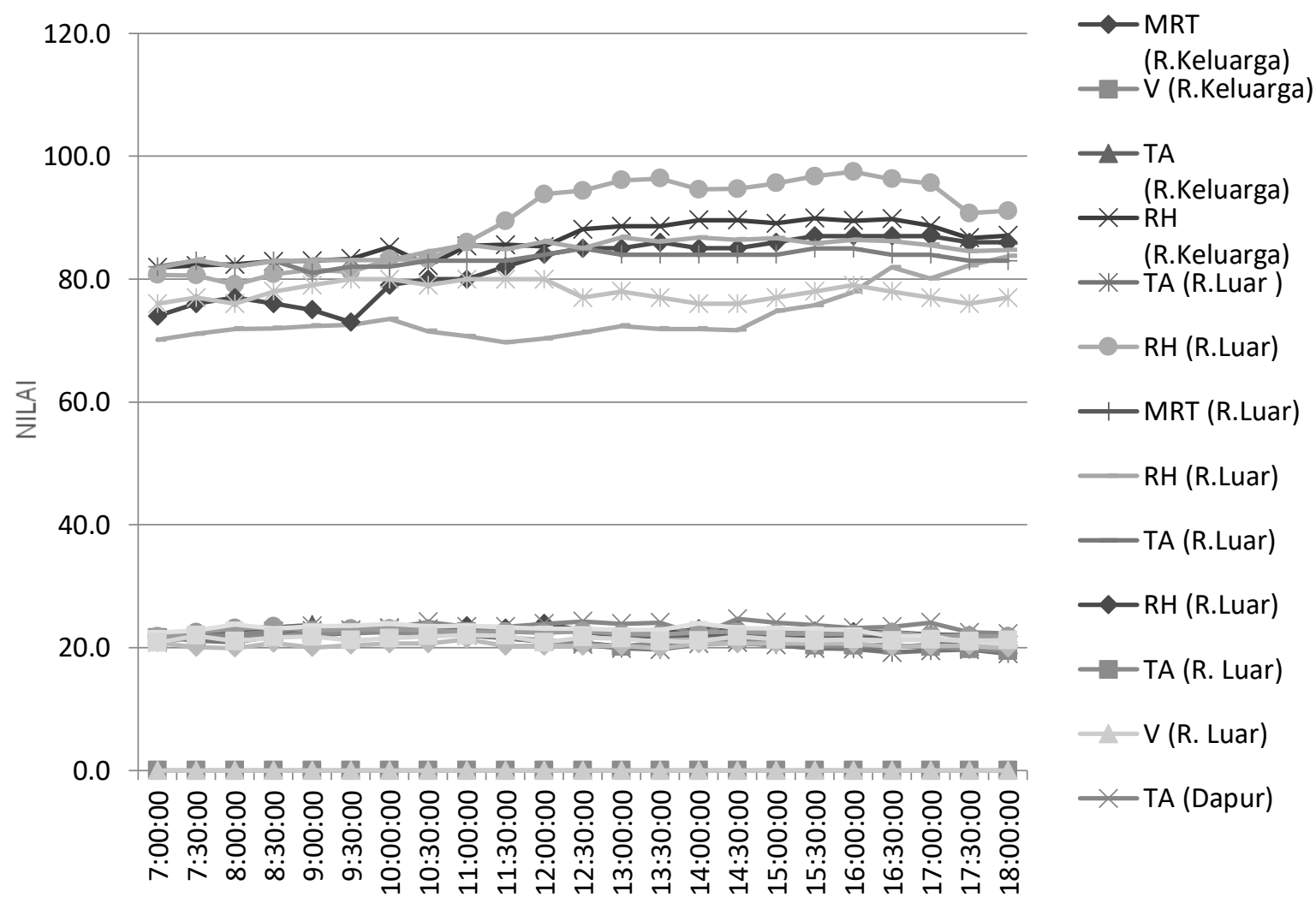

Gambar 9. Grafik Variabel Termal Rumah Ketiga (Sumber: analisis, 2021) 
Faktor yang membuat perbedaan suhu adalah posisi rumah, letak ruangan dan aktifitas penghuni rumah. Rumah sampel ketiga menghadap ke utara dengan sekeliling rumah sekitar rapat. Adanya rumah tetangga dan tebing pengaman menjadi pengaruh suhu udara lebih dingin. Ketinggian rumah yang cenderung pendek dan sebelah selatan kurang optimal pencahayaannya membuat rumah kurang mendapatkan penghawaan dan pencahayaan yang cukup. Hal ini terjadi pada ruang keluarga dan ruang tamu sehingga terasa sejuk bahkan dingin.

\subsection{Kondisi Fisik Rumah Bapak Sukarso}

Rumah sampel keempat merupakan rumah yang tergolong lama. Rumah mengahadap ke selatan dengan sisi rumah merupakan jalur pencahayaan dan penghawaan yang baik pada pagi hari. Sebelah timur rumah merupakan lahan kosong. Rumah tinggal menggunakan pondasi batu kali, dinding menggunakan material batu. Atap menggunakan seng dengan rangka dari bahan kayu keras pada langit-langit dan lantai ruang tamu masih menggunakan tanah yang diratakan.
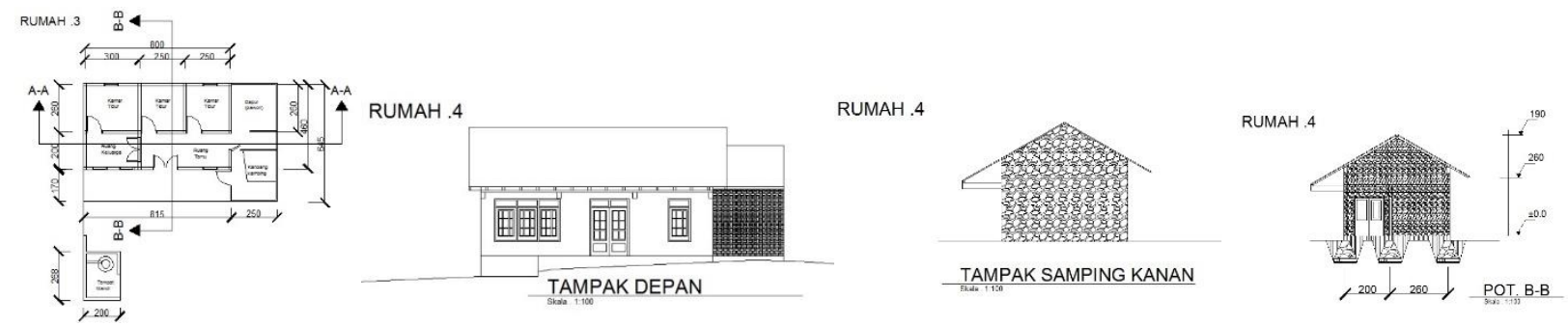

Gambar 10. Denah, Tampak dan Potongan Rumah Keempat (Sumber: analisis, 2021)

Seperti halnya rumah lainnya pintu yang digunakan mempunyai celah di bawah sekitar $2 \mathrm{~cm}$ yang membuat udara bisa masuk meskipun tidak kencang. Tidak ada plafon yang terpasang di rumah tersebut karena itu tidak menutupi pasangan atap seng yang berfungsi sebagai penahan atau pemecah suhu panas/dingin yang dihasilkan oleh atap seng. Bentuk atap berbentuk atap pelana dan ada celah atau bukaan sehingga angin bisa masuk. Ruang yang terdapat dirumah ini adalah 1 ruang tamu, 1 ruang keluarga, 3 ruang kamar, $1 \mathrm{WC} / \mathrm{kamar}$ mandi dan ruang dapur. Jendela pada setiap ruang antara lain 9 jendela kaca bening yang dipasang di ruang tamu di sebelah kanan dan kiri pintu masuk, 2 jendela di ruang kamar 1,1 jendela di ruang kamar 2, 1 jendela di ruang kamar 3, 3 jendela di ruang keluarga dan 1 jendela di ruang dapur. Arah hadap menghadap ke Utara. Hanya terdapat beberapa pohon pisang di depan rumah dengan jarak dari rumah sekitar 6-7m. Tidak terdapat tanaman sebagai vegetasi di sekitar rumah. Kedekatan rumah 1 dengan yang lainnya samping kiri adalah 2 meter, depan $10 \mathrm{~m}$, belakang $3 \mathrm{~m}$ dan samping kanan jalan gang selebar $2 \mathrm{~m}$ yang tidak berjarak dari rumah. Kebiasaan duduk penghuni yaitu lesehan menggunakan tikar dan tidak memakai kursi. tidak selalu membuka jendela pada ruang tamu karena jendela kaca, dan sering membuka jendela pada ruang kamar 1 dan kamar 2 dan kamar 3. jendela ruang kamar biasa di buka pada pukul 7 dan ditutup kembali pada pukul 4 sore. Pakaian yang dipakai biasanya ganti satu kali pada sore hari saja, dan berbahan katun. Untuk menghangatkan tubuh menggunakan pawon (tungku masak) yang dihadapkan ke badan agar terasa hangat.

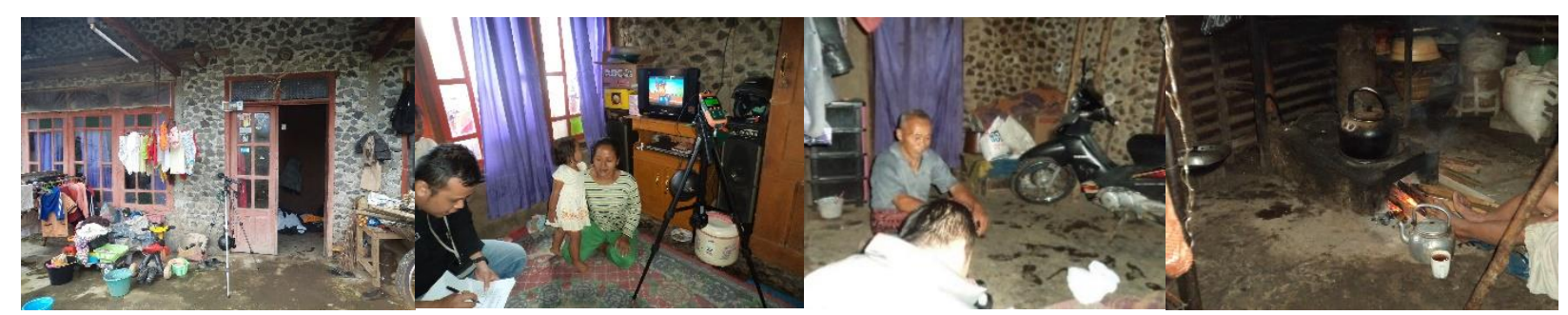

Gambar 11. Tampilan Rumah Tinggal Keempat (Sumber: analisis, 2021)

Dapur (pawon) yang ada dirumah bapak Sukarso, Dari hasil penelitian yang dimulai pagi hari pukul 07.00 WIB hingga petang pukul 18.00 WIB didapati hasil terendah atau minimum suhu ruang dapur dirumah ini yaitu $22.4^{\circ} \mathrm{C}$ pada pukul 15.00 WIB dan kelembaban terendah atau minimumnya pada ruangan dapur ini adalah $68 \%$ yaitu pukul 11.30 WIB. Sedangkan hasil maksimum atau suhu tertinggi diruang ini adalah $26.7^{\circ} \mathrm{C}$ dan kelembaban maksimumnya adalah $78 \%$ pada pukul 16.00 dan 16.30 WIB. Dan dari penelitian yang dilakukan didapatai suhu rata-rata di ruang tersebut yaitu $24.3^{\circ} \mathrm{C}$ dan kelembaban rata-ratanya adalah $74 \%$. Berikutnya adalah ruang tamu, dan dari penelitian yang dilakukan didapati suhu minimum atau suhu terendah 
pada ruang tamu tersebut yaitu $21.1{ }^{\circ} \mathrm{C}$ pada pukul 08.00 WIB dan hasil minimum atau kelembaban terendahnya diruang tamu ini adalah $81 \%$ pada pukul 12.00 WIB. Untuk suhu tertinggi atau suhu maksimum yang muncul pada ruang tamu ini adalah $23.1^{\circ} \mathrm{C}$ pada pukul $11.00 \mathrm{WIB}$ dan kelembaban maksimumnya adalah $86 \%$ pada pukul 17.00, 17.30 dan 18.00 WIB. Dan dari penelitian yang berlangsung yang dimulai dari pagi hari hingga petang didapati hasil rata-rata penelitian tersebut,untuk rata-rata suhu yang ada pada ruang tamu tersebut didapati hasil $22.0{ }^{\circ} \mathrm{C}$ dan hasil rata-rata kelembaban ruang tamu tersebut adalah $85 \%$.

Untuk ruang luar atau teras pada rumah ini didapat hasil suhu terendah atau suhu minimumnya yaitu $21.0^{\circ} \mathrm{C}$ pada pukul 18.00 WIB dan hasil terendah dari kecepatan hembusan angin pada ruang luar atau teras rumah ini adalah 0.0. dan hasil suhu tertinggi pada ruang luar atau teras tersebut adalah $25.8^{\circ} \mathrm{C}$, hasil tertinggi kecepatan angin maksimumnya adalah $0.0 \%$. Dari hasil penelitian ruang luar atau teras pada rumah ini didapati hasil rata-ratanya, untuk rata-rata suhu yang didapati adalah $22.5^{\circ} \mathrm{C}$ dan hasil rata-rata kecepatan anginnya adalah 0.0, yang diukur menggunakan alat anemometer. Suhu terendah kamar tidur sebesar $20.81^{\circ} \mathrm{C}$ dan hasil terendah atau kelembaban minimumnya adalah $85.29 \%$, sedangkan hasil tertinggi atau suhu maksimum yang didapati pada ruang ini adalah $22.99^{\circ} \mathrm{C}$ pada pukul 16.30 WIB dan hasil teringgi atau kelembaban maksimumnya adalah $91.59 \%$ pada pukul 10.00 WIB. Dari penelitian yang dimulai dari pagi hari hingga petang didadapti hasil rata-ratnya yaitu untuk hasil rata-rata suhu diruang ini adalah $22.26^{\circ} \mathrm{C}$ dan hasil ratarata kelembaban pada ruang ini adalah $87.00 \%$.

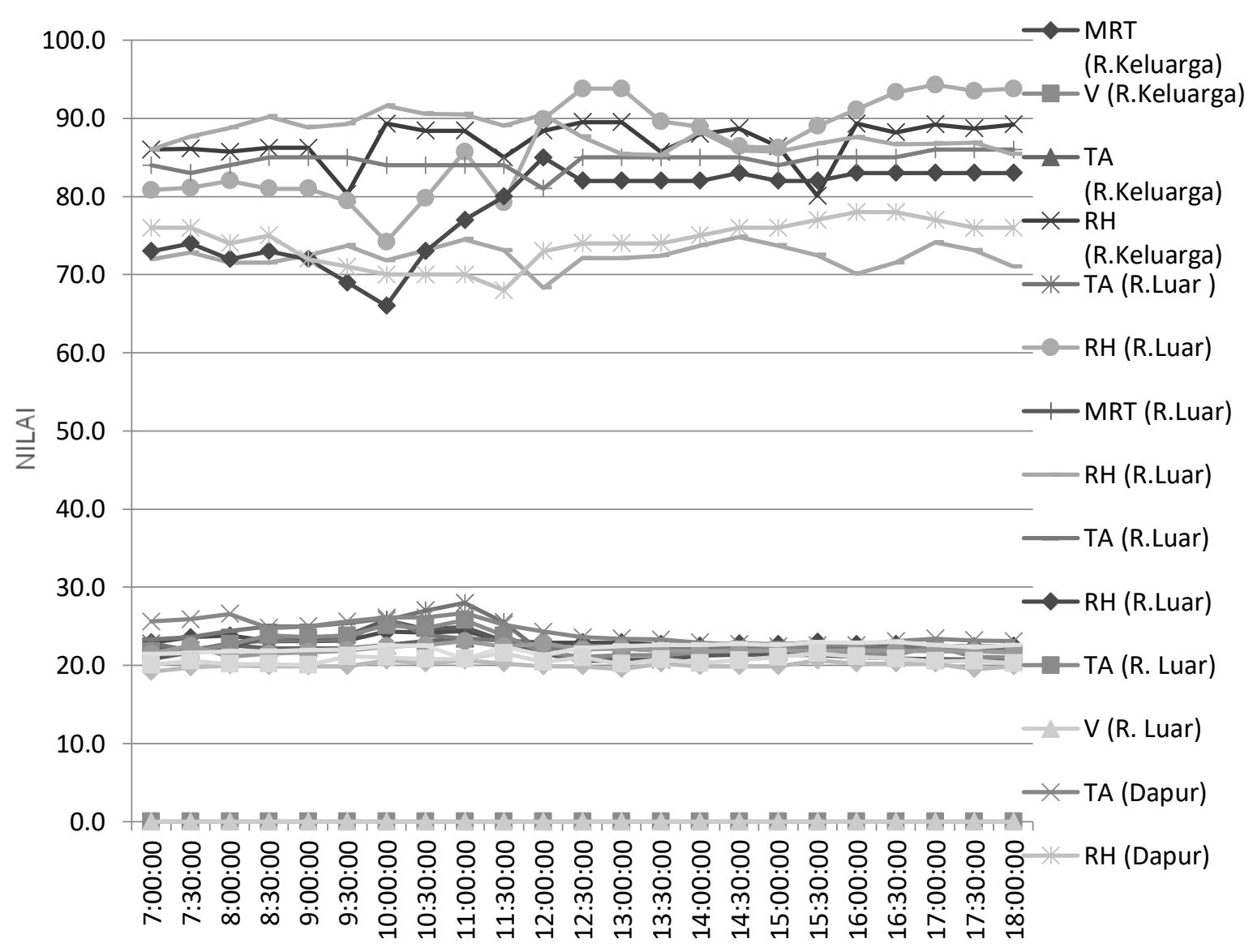

Gambar 12. Grafik Variabel Termal Rumah Keempat (Sumber: analisis, 2021)

Dari pengukuran tiap ruang yang ada dirumah ini dismpulkan bahwa tiap ruang mempunyai suhu serta kelembaban yang berbeda-beda, salah satu faktor yang mempengaruhi perbedaan itu adalah lokasi rumah, rumah ini termasuk rumah yang berdiri didataran yang agak rendah dikampung ini, serta sekeliling rumah yang merupakan perkebunan masyarakat, rumah ini mendapatkan penghawaan dan pencahayaan yang maksimum, sedangkan untuk posisi ruang dirumah ini ruang tamu atau keluarga adalah ruang yang sedikit lebih lembab diantara ruang lainya, ruang tamu berada dipaling depan dan rumah ini menghadap Utara, meskipun pencahayaan dan penghawaan cukup namun kehangatan pada ruang ini cenderung kurang pada pagi hari. Lantai yang masih menggunakan tanah, dan belum banyaknya barang yang ada diruang tamu ini menurut saya 
juga menjadi pengaruh terhadab suhu dan kelembaban yang ada. Penelitian pada rumah ini ruang tidur 1 dan ruang keluarga adalah ruang yang dengan intensitas tinggi paling mendapatkan penghawaan serta pencahayaan yang cukup tinggi, ruang yang berada paling belakan mendapat sinar matahari sore hari yang hangat sehingga dapat menjadikan kelembaban ruangan ini stabil. Faktor yang lain disini adalah aktifitas, rumah yang hanya berisi 3 orang dan sedikit aktifitas karena penghuni lebih banyak melakukan aktifitasnya diluar menurut saya akan mempengaruhi suhu yang ada didalam ruangan menjadi kurang hangat.

\subsection{Kondisi Fisik Rumah Bapak Nursalim}

Rumah Batu pak Nursalim sama seperti rumah pada umumnya, Batu kali menjadi bahan utama pondasi yang digunakan, lantai yang masih menggunakan tanah diratakan dan dipadatkan, dinding menggunakan paangan Batu kali, untuk atap menggunakan seng dan menggunakan plafon kayu keras sekaligus sebagai lantai 2 pada langit-langitnya, untuk penggunaan jendela, rumah Batu pak Nursalim ini beda tidak seperti rumah Batu lainya, pintu dan jendela yang menggunakan kayu dan dipasang kaca, untuk letak rumah ini adalah mengahadap ke Selatan sisi timur adalah lorong dengan lebar lorong $1.5 \mathrm{~m}$, jarak dinding rumah dengan lorong sebelah timur rumah adalah tidak berjarak sama sekali, jadi dinding rumah langsung lorong menuju rumah bapak Sukarso dan sebelah utaranya adalah rumah tinggal milik tetangga yang terbuat dari pasangan batu kali, yang menjadi sirkulasi pencahayaan serta penghawaan yang baik adalah sisi Depan rumah yaitu sebelah selatan rumah terdapat Jalan Utama selebar $2.5 \mathrm{~m}$, sedangkan jarak rumah dengan jalan utama berjarak $2 \mathrm{~m}$ pada pagi hari rumah ini mendapat pengahawaan yang optimal tepat pada ruang tamu dan ruang depan.
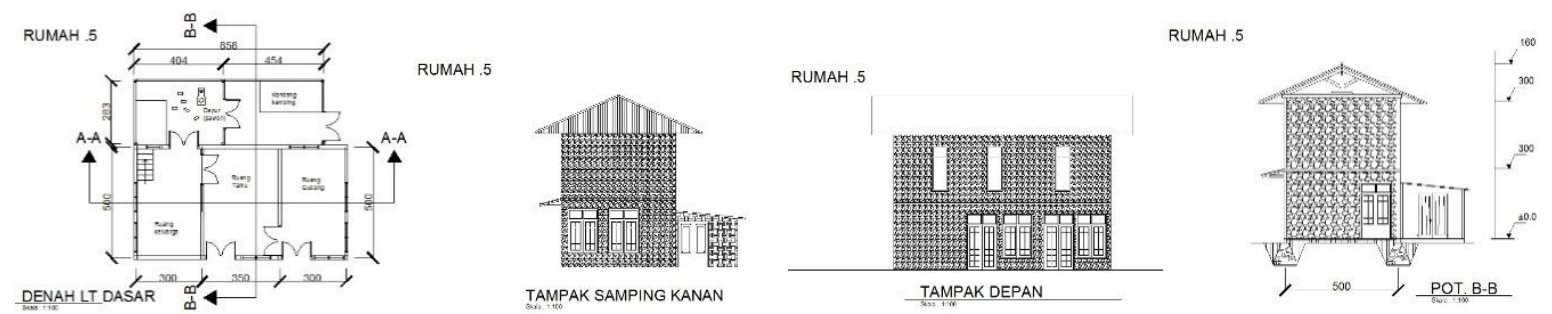

Gambar 13. Denah, Tampak dan Potongan Rumah Kelima (Sumber: analisis, 2021)

Bentuk pintu berbentuk pintu pada umumnya dan ada celah yang ada di antara lantai dan pintu dengan kerenggangan sekitar $2 \mathrm{~cm}$, berwarna kayu mentah/tidak dicat. Ada plafon yang terpasang di rumah tersebut dan sekaligus sebagai lantai 1 dan untuk membatasi radiasi panas yang dihasilkan oleh atap seng. dan ada celah sekitar $20 \mathrm{~cm}$ yang terlihat dari lantai yang menyebabkan angin dan sinar matahari bisa masuk. Bentuk atap rapat dan tidak ada lubang di atapnya, tetapi ada celah di antara kusen dengan dinding pertemuan atap. Ruang terdiri dari 1 ruang tamu, 2 ruang kamar 1 ruang dapur+ruang keluarga dan di belakang rumah 1 wc non permanen dan tidak ada perabot yang ada. Ruang tamu dipasangkan 5 daun jendela angin dan cahaya bisa masuk karena jendela menggunakan kayu dan kaca yang rapat dan dipasangkan kaca juga khorden yang dipasangkan di jendela. Tiap kamar menggunakan jendela yang bisa dibuka, dan pada dapur menggunakan bouvent yang bisa dibuka sehingga cahaya matahari dan angin bisa masuk. Arah hadap menghadap ke Selatan. Ruang tamu terletak di sebelah ruang kamar, dapur berhadapan langsung dengan kamar dan ruang keluarga, pada posisi rumah tersbut cahaya pagi hari masuk ke ruang tamu karena dipasangkan pintu dan ruang kamar tidak mendapatkan cahaya, pada ruang dapur mendapatkan cahaya pada sore hari karena terletak di sebelah barat. Tidak ada tanaman di lingkungan sekitar rumah. Kedekatan rumah pak Nursalim dengan yang lain berjarak sekitar 1,5 meter. Kebiasaan duduk penghuni yaitu lesehan menggunakan tikar dan tidak memakai kursi. tidak selalu membuka jendela pada ruang tamu, dan sering membuka jendela pada ruang kamar. Jendela ruang kamar biasa di buka pada pukul 7 dan ditutup kembali pada pukul 4 sore. Pakaian yang dipakai biasanya ganti dua kali pada pagi hari dan sore hari, dan berbahan katun. Untuk menghangatkan tubuh menggunakan pawon (tungku) masak yang dihadapkan ke badan agar terasa hangat.

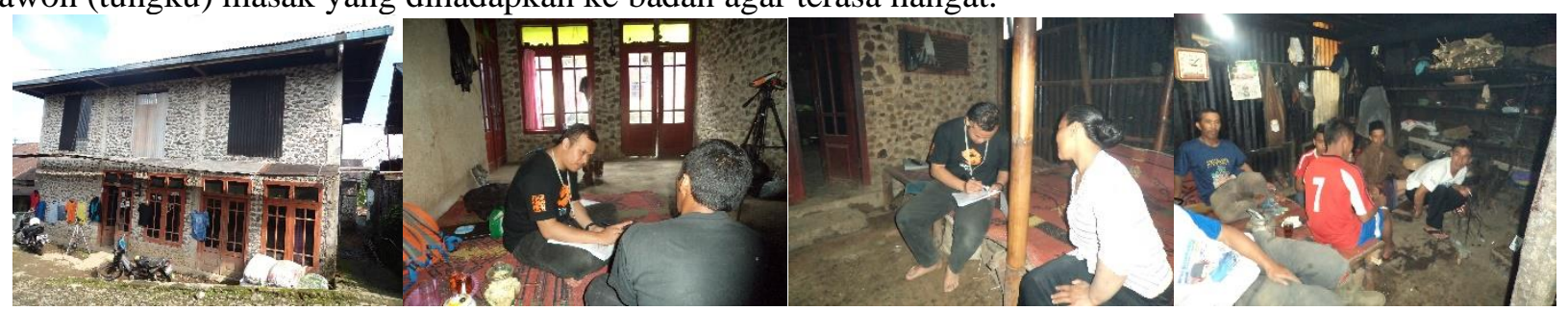

Gambar 14. Tampilan Rumah Tinggal Kelima (Sumber: analisis, 2021) 
Ruang dapur (pawon) yang ada dirumah bapak Sutaman, Dari hasil penelitian yang dimulai pagi hari pukul 07.00 WIB hingga petang pukul 18.00 WIB didapati hasil terendah atau minimum suhu ruang dapur dirumah ini yaitu $23.4^{\circ} \mathrm{C}$ pada pukul 07.30 dan 14.00 WIB dan kelembaban terendah atau minimumnya pada ruangan dapur ini adalah 74\% yaitu pukul 07.00, 08.00, 17.30 dan 18.00 WIB. sedangkan hasil maksimum atau suhu tertinggi diruang ini adalah $25.7^{\circ} \mathrm{C}$ dan kelembabab maksimumnya adalah $86 \%$ pada pukul 12.30 WIB. Dan dari penelitian yang dilakukan didapatai suhu rata-rata dirumah tersebut yaitu $24.4^{\circ} \mathrm{C}$ dan kelembaban rata-ratanya adalah $79 \%$. Ruang tamu, dan dari penelitian yang dilakukan didapati suhu minimum atau suhu terendah pada ruang tamu tersebut yaitu $20.4{ }^{\circ} \mathrm{C}$ pada pukul $17.00 \mathrm{WIB}$ dan hasil minimum atau kelembaban terendahnya diruang tamu ini adalah $79 \%$ pada pukul 11.00 dan 11.30 WIB. Untuk suhu tertinggi atau suhu maksimum yang muncul pada ruang tamu ini adalah $22.4{ }^{\circ} \mathrm{C}$ pada pukul 07.00, 08.00 dan 08.30 WIB dan kelembaban maksimumnya adalah $86 \%$ pada pukul 12.00, 14.30, 15.00, 16.00, 16.30, 17.00 dan 17.30WIB. Dan dari penelitian yang berlangsung yang dimulai dari pagi hari hingga petang didapati hasil ratarata penelitian tersebut,untuk rata-rata suhu yang ada pada ruang tamu tersebut didapati hasil $21.6^{\circ} \mathrm{C}$ dan hasil rata-rata kelembaban ruang tamu tersebut adalah $84 \%$.

Ruang luar atau teras pada rumah ini didapati hasil suhu terendah atau suhu minimumnya yaitu $19.8^{\circ} \mathrm{C}$ dan hasil terendah dari kelembaban ruang luar atau teras rumah ini adalah $73 \%$. dan hasil suhu tertinggi pada ruang luar luar atau teras tersebut adalah $24.4^{\circ} \mathrm{C}$, hasil tertinggi atau kelembaban maksimumnya adalah $94 \%$. Dari hasil penelitian ruang luar atau teras pada rumah ini didapati hasil rata-ratanya, untuk rata-rata suhu yang didapati adalah $21.9^{\circ} \mathrm{C}$ dan hasil rata-rata kelembabanya adalah $87 \%$. Ruang tidur, dari ruangan ini didapati hasil suhu terendah atau suhu minimum yaitu $87.15^{\circ} \mathrm{C}$ pukul $08.00 \mathrm{WIB}$ dan hasil terendah atau kelembaban minimumnya adalah $21.52 \%$ pukul $18.00 \mathrm{WIB}$, sedangkan hasil tertinggi atau suhu maksimum yang didapati pada ruang ini adalah $23.60^{\circ} \mathrm{C}$ dan hasil teringgi atau kelembaban mak simalnya adalah $94.40 \%$. Dari penelitian yang yang dimulai dari pagi hari hingga petang didapti hasil rata-ratnya yaitu untuk hasil rata-rata suhu diruang ini adalah $22.59{ }^{\circ} \mathrm{C}$ dan hasil rata-rata kelembaban pada ruang ini adalah $91.21 \%$.

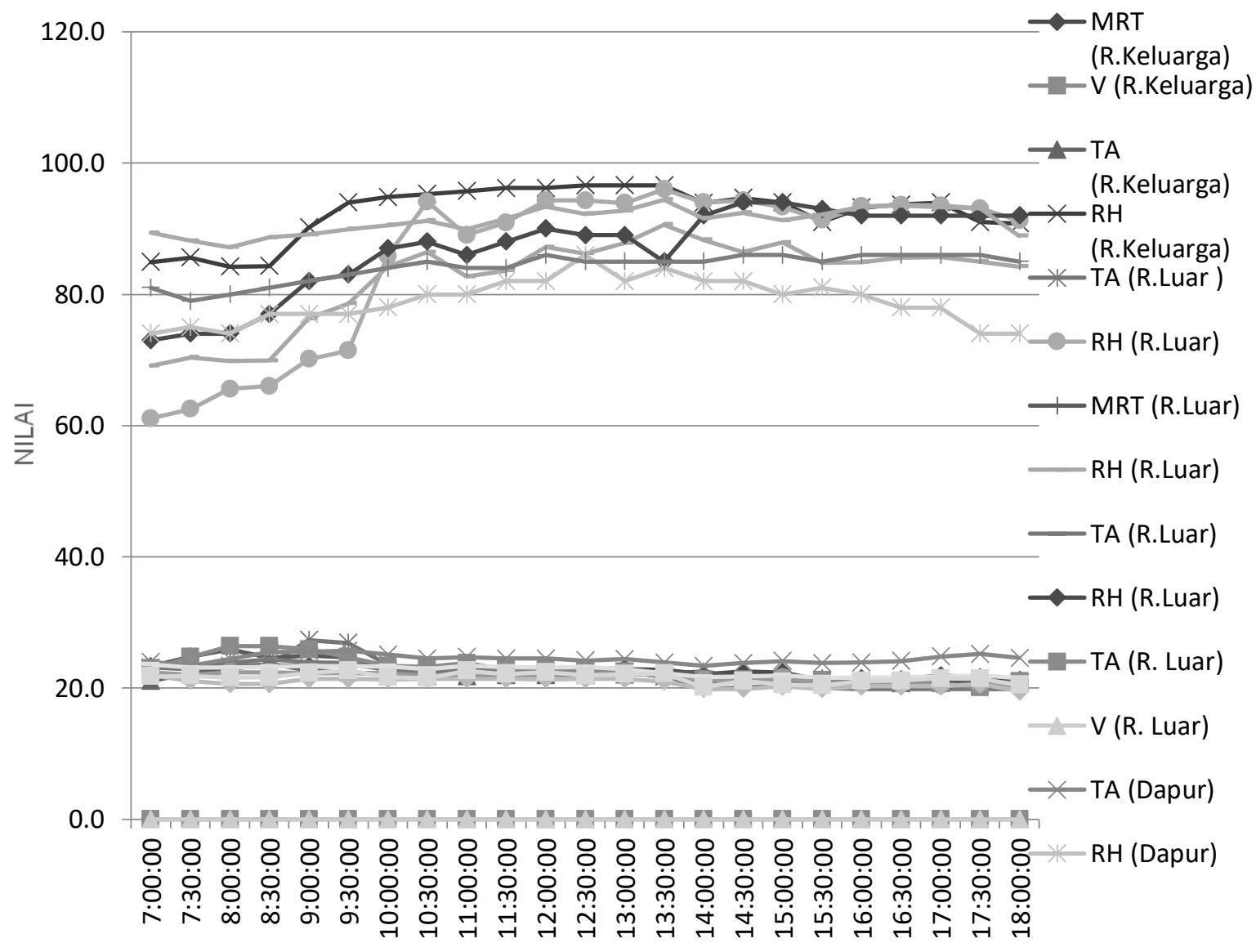

Gambar 15. Grafik Variabel Termal Rumah Kelima (Sumber: analisis, 2021) 
Dari hasil penelitian tiap ruang diatas tentunya ada selisih serta perbedaan hasil terendah dan teringgi pada setiap suhu dan kelembabanya, suhu dan kelembaban tertinggi pada ruang yang ada adalah ruang dapur atau ruang keluarga, kebetulan ruang keluarga jadi satu dengan ruang dapur yang setiap harinya dijadikan tempat berkumpul keluarga usai menyelsaikan aktivitasnya di luar rumah, ruang dapur dan ruang keluarga mungkin satu-satunya tempat yang nyaman buat anggota keluarga, karena pada ruang tamu sebuah televisi pun tidak ada, banyaknya aktifitas diruang dapur dan ruang keluarga mungkin satu-satunya faktor yang membuat suhu menjadi naik seperti data diatas yaitu $25.7^{\circ} \mathrm{C}$, untuk kelembaban disini adalah $86 \%$. Dipengaruhi oleh letak ruangan serta bukaan yang ada, namun secara keseluruhan bahwa rumah ini sebenarnya harusnya setiap ruangan memiliki kondisi suhu serta kelembaban yang baik, karena ruangan cenderung vertikal menghadap ke selatan dan pada sisi utara terdapat bukaan yang cukup untuk mendapatkan pencahayaan serta penghawaan yang baik. Untuk ruang lain cenderung lebih rendah suhunya, karena kurangnya aktifitas yang ada karena diketahui rumah ini hanya berisi 5 orang, dan seorang ayah yang lebih banyak beraktifitas diluar untuk bekerja dimulai pagi hari dan pulang petang. Rumah yang banyak bukaan mengingat pintu dan jendela masih menggunakan kayu dn kaca sederhana sewajarnya tempat keluar masuk orang dan angin yang sebenarnya jauh dari standar, serta tidak adanya plafon serta bangunan yang kurang rapat, seperti pada ruang tamu yang menghasilkan suhu terendah yaitu $20.7^{\circ} \mathrm{C}$.

\subsection{Karakter Termal Bangunan}

Rumah batu ekspos di tropis pegunungan mempunyai orientasi yang bervariasi. Beberapa penghuni di Desa Kwadungan yang masih percaya dengan nilai spiritual gunung tidak akan membuat rumah dengan menghadap gunung. Namun, beberapa penghuni sudah tidak mempercayai nilai spiritual gunung sehingga orientasi didasarkan pada aspek jalan yang ada. Orientasi bangunan akan mempengaruhi pencahayaan dan penghawaan alami yang masuk ke dalam bangunan. Sinar matahari menjadi faktor yang berpengaruh dalam penciptaan kenyamanan termal dalam bangunan (Tyas et al., 2015). Sirkulasi udara di dalam rumah batu ekspos lebih mudah tercapai karena kecepatan udara di lingkungan pegunungan lebih kencang. Volume ruang pada rumah batu ekspos tergolong cukup besar sehingga udara lebih mudah bergerak. Namun, penghuni rumah batu ekspos merasa kedinginan pada saat udara yang ada di dalam ruang terlalu besar. Hal ini berbeda dengan lokasi di dataran rendah yang cenderung panas dan memerlukan sirkulasi udara untuk penciptaan kenyamanan termal (Latif et al., 2016). Keberadaan plafon bisa membantu bangunan dalam menciptakan kenyamanan termal dengan cara mereduksi panas yang masuk (Santoso \& Santosa, 2013). Rumah batu ekspos di daerah pegunungan akan berbeda perlakuannya karena iklim yang berbeda dengan dataran rendah. Iklim dingin tidak memerlukan reduksi panas karena sinar matahari jarang bersinar pada daerah pegunungan. Sinar matahari cenderung tertutup oleh awan. Rumah batu ekspos cenderung tidak menggunakan plafon.

Rumah tinggal di daerah dingin identik dengan penggunaan perapian dalam menciptakan kenyamanan termal penghuni. Peletakan dapur sebagai ruang perapian menjadi aspek yang diperhitungkan untuk menciptakan keberhasilan desain arsitektur (Susanti \& Gaguk, 2019). Kenyamanan termal sangat penting untuk dijadikan dasar dalam pembuatan desain arsitektur (Suseno et al., 2020). Rumah batu ekspos di Desa Kwadungan, Wonosobo menggunakan perapian sebagai unsur untuk menciptakan kenyamanan termal. Peletakan pawon tidak di tengah ruangan. Peletakan pawon di belakang rumah tinggal, namun terdapat pintu belakang yang bisa menghubungkan pawon langsung ke ruang luar ataupun ke rumah kerabat sebelah rumah. Sebagian besar ventilasi pada rumah batu ekspos di Desa Kwadungan tertutup. Penghuni berpendapat bahwa iklim dingin di luar bangunan dapat dikurangi dengan cara menutup ventilasi. Cahaya matahari masih mampu masuk ke dalam bangunan dengan penggunaan kaca pada ventilasi. Bentuk dan ukuran ventilasi menjadi tidak berpengaruh karena ventilasi menjadi ventilasi mati. Pengaruh bentuk dan ukuran hanya pada pencahayaan semata. Hal ini berbeda dengan rumah tinggal di dataran rendah yang memerlukan angin agar sirkulasi udara menjadi lancara. Bentuk dan ukuran ventilasi pada rumah tinggal di dataran rendah menjadi faktor yang mempengaruhi kenyamanan termal (Razak, 2015). Dinding pada rumah batu ekspos terbuat dari material batu. Pada rumah tradisional di dataran rendah sebagian besar menggunakan dinding yang terbuat dari material kayu. Kayu dianggap material mempunyai pengaruh dalam mereduksi panas (Latif et al., 2019). Rumah batu eskpos di daerah pegunungan terletak di lingkungan beriklim dingin sehingga reduksi panas tidak begitu diperlukan. Material batu dianggap bisa menahan angin yang menerpa bangunan. Material dinding batu ekspos dianggap bisa memberikan perlindungan bagi penghuni di daerah tropis pegunungan. Suhu permukaan dinding bangunan akan mempengaruhi kinerja termal bangunan (Hendriani et al., 2017) 


\section{Kesimpulan}

Arah hadap atau orientasi bangunan menjadi faktor penting yang mempengaruhi karakteristik termal. Sinar matahari yang masuk ke dalam bangunan terkait dengan peletakan suatau ruang akan menyebabkan perbedaan termal yang ada dalam suatu ruang. Aspek lain adalah kerapatan bangunan yang membuat keleluasaan cahaya matahari untuk measuk ke dalam bangunan. Kecepatan angin akan terpengaruh oleh kerapatan bangunan di sekitar. Rumah tinggal di daerah tropis pegunungan mampu mendapatkan sinar matahari namun tidak sebesar rumah tinggal di daerah dataran rendah. Penghuni merasa pengurangan angin menjadi solusi dalam mempertahankan kenyamanan termal dengan cara menutup ventilasi. Kecepatan angin di daerah pegunungan cenderung kencang sehingga penghuni merasa perlu untuk mengurangi masuknya angin ke dalam rumah.

Volume ruang di dalam bangunan bervariasi. Kecenderungan bangunan tidak mempunyai plafon membuat bangunan semakin dingin. Penghuni merasa tidak menggunakan plafon karena keterbatasan biaya pembangunan rumah. Selain itu, penghuni merasa plafon hanyalah aksesoris semata. Ketiadaan plafon membuat volume ruang semakin besar sehingga angin semakin mudah untuk bergerak dan membuat ruang menjadi lebih dingin. Saat matahari bersinar, rumah menjadi lebih hangat karena tidak terhalang oleh plafon. Ukuran sebagian ruang tidak terlalu besar karena keterbatasan perekonomian penduduk. Sebagian rumah mempunyai ruang depan yang luas untuk menjemur atau mengeringkan hasil pertanian. Ruang depan yang luas dikenal dengan nama jogan.

Penggunaan perapian menjadi dominan dalam menciptakan kenyamanan termal bagi penghuni. Aktivitas yang dilakukan penghuni seringkali dilakukan di dapur. Penghuni bersama dengan tetangga sering mengobrol di dapur sambil menghangatkan badan. Penghuni menganggap bahwa ngendong (mengobrol) dapat menambah kerukunan. Perapian menjadi salah satu unsur bangunan yang mampu menghangatkan ruang. Material batu menjadi salah satu usaha masyarakat dalam menahan angin yang cukup kuat di daerah pegunungan. Karakteristik rumah batu ekspos di tropis pegunungan yang mempengaruhi kenyamanan termal meliputi dinding batu ekspos, tanpa plafon, ventilasi cenderung tertutup dari angin dan mempunyai perapian.

\section{Referensi}

Aprita, D. R., \& Anisa, A. (2020). Arsitektur Tropis Pada Tata Ruang Dan Permukiman Di Kampung Pulo Garut. Jurnal Arsitektur ZONASI, 3(3), 413-421. https://doi.org/10.17509/jaz.v3i3.26692

Hakiki, R., Aldy, P., \& Hidayat, W. (2020). Sekolah Tinggi Migas Duri Dengan Penerapan Passive Cooling. Jurnal Arsitektur ZONASI, 3(3), 299-312. https://doi.org/10.17509/jaz.v3i3.26502

Hendriani, A. S., Hermawan, \& Retyanto, B. (2017). Comparison analysis of wooden house thermal comfort in tropical coast and mountainous by using wall surface temperature difference. AIP Conference Proceedings, 1887. https://doi.org/10.1063/1.5003490

Hermawan. (2014). Prediksi Kenyamanan Termal Dengan Pmv. Jurnal PPKM UNSIQ, 1(1), 13-20.

Hermawan, H. (2018). Studi lapangan variabel iklim rumah vernakular pantai dan gunung dalam menciptakan kenyamanan termal adaptif. Jurnal Arsitektur ZONASI, 1(2), 96. https://doi.org/10.17509/jaz.v1i2.12467

Hermawan, H., \& Fikri, M. (2020). Kinerja termal rumah berdinding kayu, atap genteng dan lantai tanah di tropis hangat. Jurnal Ilmiah Arsitektur, 10(2), 54-60.

Hermawan, H., Hadiyanto, H., Sunaryo, S., \& Kholil, A. (2019). Analysis of thermal performance of wood and exposed stone-walled buildings in mountainous areas with building envelop variations. Journal of Applied Engineering Science, 17(3), 321-332. https://doi.org/10.5937/jaes17-20617

Hermawan, H., \& Prianto, E. (2018). Thermal evaluation for exposed stone house with quantitative and qualitative approach in mountainous area, Wonosobo, Indonesia. IOP Conference Series: Earth and Environmental Science, 99(1). https://doi.org/10.1088/1755-1315/99/1/012017

Latif, S., Hamzah, B., \& Ihsan, I. (2016). Pengaliran Udara Untuk Kenyamanan Termal Ruang Kelas Dengan Metode Simulasi Computational Fluid Dynamics. Sinektika: Jurnal Arsitektur, 14(2), 209-216. https://doi.org/10.23917/sinektika.v14i2.1438

Latif, S., Hamzah, B., Rahim, R., Mulyadi, R., Arsitektur, D., Teknik, F., Hasanuddin, U., Selatan, S., Arsitektur, P., Teknik, F., \& Makassar, U. M. (2019). Thermal Comfort Identification of Traditional Bugis House in Humid Tropical Climate. Tesa Arsitektur, 17(1), 61-71. https://doi.org/10.24167/tesa.v17i1.1803

Razak, H. (2015). pengaruh Karakteristik Ventilasi dan Lingkungan Terhadap Tingkat Kenyamanan Termal Ruang Kelas SMPN di Jakarta Selatan. Jurnal Penelitian Dan Karya Ilmiah Arsitektur Usakti, 15(2), 118. https://doi.org/10.25105/agora.v15i2.2024 
Santoso, B., \& Santosa, M. (2013). Kinerja Termal Bangunan Pada Lingkungan Berkepadatan Tinggi Dengan Variabel Atap, Dinding, Ventilasi Dan Plafon. Gema Teknik.

Susanti, D., \& Gaguk, S. (2019). Dapur Sebagai Dasar Penataan Ruang. 3(1), 11-24.

Suseno, T. A., Arsitektur, P. S., \& Teknik, F. (2020). WONOSOBO CULTURE CENTRE DENGAN PENDEKATAN KENYAMANAN TERMAL. 1(2), 387-391.

Tyas, W. I., NABILAH, F., PUSPITA, A., \& SYAFITRI, S. I. (2015). Orientasi Bangunan Terhadap Kenyamanan Termal pada Rumah Susun Leuwigajah Cimahi. Jurnal Reka Karsa, 3(1), 1-12.

Vidiyanti, C., Siswanto, R., \& Ramadhan, F. (2020). Pengaruh Bukaan Terhadap Pencahayaan Alami Dan Penghawaan Alami Pada Masjid Al Ahdhar Bekasi. Jurnal Arsitektur ZONASI, 3(1), 20-33. https://doi.org/10.17509/jaz.v3i1.18621 